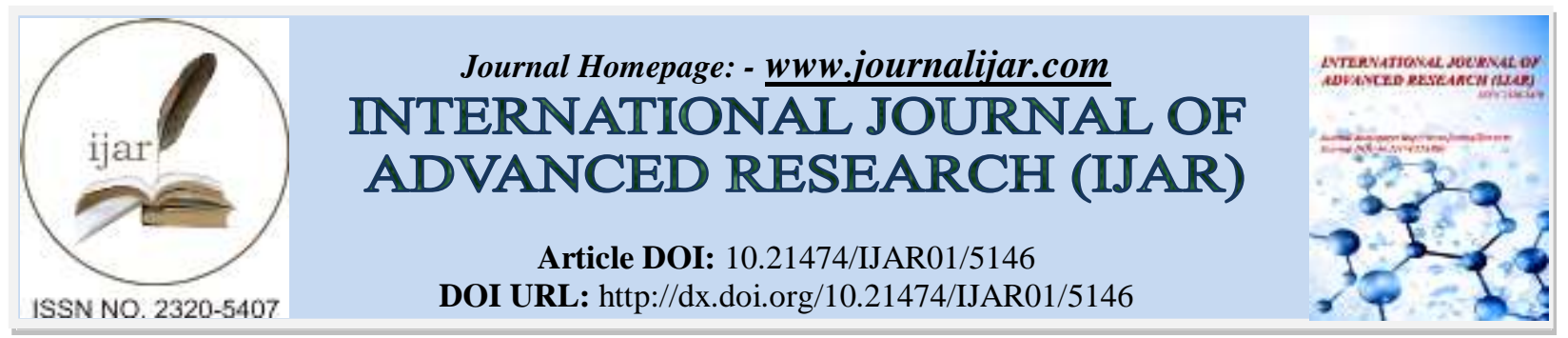

RESEARCH ARTICLE

\title{
STUDY OF ENVIRONMENTAL FAVORABLE BIO-GAS TO GENERATE ELECTRICITY IN INDIA: REVIEW.
}

Satish Kumar ${ }^{1}$ and Govind Kumar Maurya ${ }^{2}$.

1. M.Tech Student, School of Electrical and Electronic Engineering, Ajay Kumar Garg Engineering College1 Ghaziabad, U.P., India.

2. Assistant Scientific Officer, National Institute of Plant Health Management, Rajendranagar, Hyderabad, TN. India.

\section{Manuscript Info}

Manuscript History

Received: 12 June 2017

Final Accepted: 14 July 2017

Published: August 2017

Key words:-

Biogas, waste sources, carbon credits, recycling, waste gas treatment, smart grid.

\section{Abstract}

Bio-gas is provided a clean energy to the Country. It is easily controller renewable energy from the wood, waste of animals, home waste, organic waste etc. Because the higher heat value (HHV) of biogas is $8.4-13.1 \mathrm{kWh} / \mathrm{m}^{3}$. Mainly India has agriculture part in the village area that also used in to produce the biogas by using this we can meet the demand of energy in the village area. Due to the deforestation the wood is more scaring so we to move the other biogas of resource. The especially design biogas engine with advance feature like modified piston, ignition system controller, compression ratio can be used.

This system can be connecting with the help of alternators with the smart grid or micro-grid or local electricity grids by synchronized panel. If we generate the more bio gas then used for the cooking purpose in the village area to the minimize for LPG or kerosene.

In India there are some states that produce the energy from biogas like Tamilnadu, Utter Pradesh, Madhya Pradesh, and Gujarat. Developing country like India, Bangladesh, and Myanmar etc government try hard to reach the maximum power generation. In this paper mainly focus on the biogas controller and improvement to maximize the energy in the village area to provided electricity.

Copy Right, IJAR, 2017,. All rights reserved.

\section{Introduction:-}

Till now a day in India many part of rural area no electricity for the full day or even no electricity. This problem is arising due the peak power demand and average power demand increasing yearly. [1] So we more focus on the renewable energy sources, wind energy, solar energy, or the hydro power energy.[2] Indian farmer can be used their waste as gold. The husks, weeds, cow waste, and other agriculture waste are thinking useless but by using conversion into sustainable, nonpolluting and very cheap energy that will gave them to improve the daily life at the village area that change the lives.

According to the government claims that an estimated 310,000 of India half of the millions have electricity but the reality is that this energy is the unreliable, irregular and low power quality.

Corresponding Author:- Satish Kumar.

Address:- Govind Kumar Maurya, National Institute of Plant Health Management, Budwel,

Rajendranagar, Hyderabad, Telangana India 500030. 
Biogas is produced by micro-organisms in the nonattendance of air by an alleged anaerobic digestion. Mechanical biogas is delivered at sewage treatment plants (sludge fermentation stage), landfills, and locales with mechanical handling industry and at assimilation plants for agrarian natural waste, both mesophilic $\left(35^{\circ} \mathrm{C}\right)$ and thermophilic $(55$ ${ }^{\circ} \mathrm{C}$ ). Biogas from anaerobic absorption what's more, landfills comprises principally of CH4 and $\mathrm{CO} 2$ [9].

About 80,000 villages in India have no electricity because of the government cannot either feasible or economical connect them to conventional electricity. There are some of village that can even experience the electricity or the power that mean there is no source of power not even a diesel cost generator.

In the July Department of Non-Conventional Energy Sources (DNEC-1996) give the announcement some of the new project that would use biogas or the organic waste to required energy demand that are needed to the 25,000 remote village area where the electricity can't be reach. Government said that this energy plan will give the 100 houses with approx 500 people are get benefit with the investments of the approx two millions in the 2012 [4].The observational show that sawdust has higher gasification efficiency than rice husk. The first reason is that the size of sawdust is smaller than that of rice husk, which affects the gasification efficiency. Small particles with larger special surface area are easier to react with gasification reagent, and then the produced gas diffuses to the surroundings more rapidly.
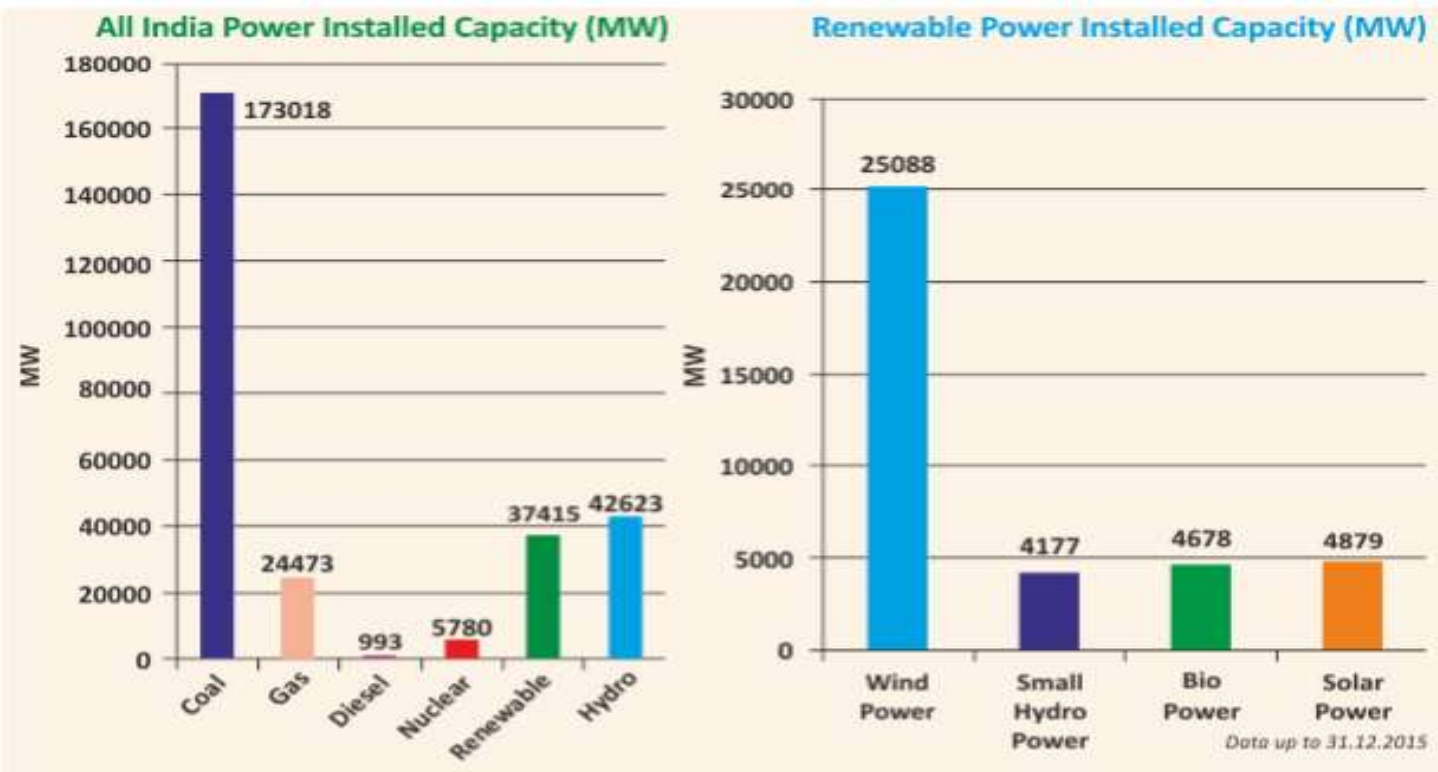

Figure 1:- All India power installed capacity and renewable installed capacity (In MW) [5]

But now a day Ministry of New and Renewable Energy (MNRE-2006) during 15-17 February it is target to move from megawatts to giga watts. As of December 2014, solar, wind, biomass and little hydropower contribute around 13 for every penny of the aggregate introduced limit with respect to power. The aggregate introduced limit touched the figure of 33,791 MW with wind power contributing 22,465 MW, solar energy 3,062 MW, Bio energy 4,272 and Small hydro 3,990 MW [5].

Around 960 million tons of strong waste is being created every year as side-effects amid modern, mining, city, agrarian and different procedures. Of this 350 million tons are natural squanders from farming sources; 290 million tons are inorganic misuse of modern and mining areas and 4.5 million tons are unsafe in nature [6].

Advances in solid waste organization realized choice improvement materials as a substitute to standard materials like squares, pieces, tiles, sums, stoneware generation, bond, lime, soil, timber and paint. To ensure the earth, attempts are being made for reusing different misuses and utilize them in regard included applications [6].

Sustainable power source ability to $175 \mathrm{GW}$ by the year 2022 which incorporates $100 \mathrm{GW}$ from sun powered, 60 GW from wind, $10 \mathrm{GW}$ from bio-power and $5 \mathrm{GW}$ from little hydro-control [5]. 
Tentative State- wise break- up of $10 \mathrm{GW}$ Biomass Power Under

Renewable Power Target of 175 GW by 2022

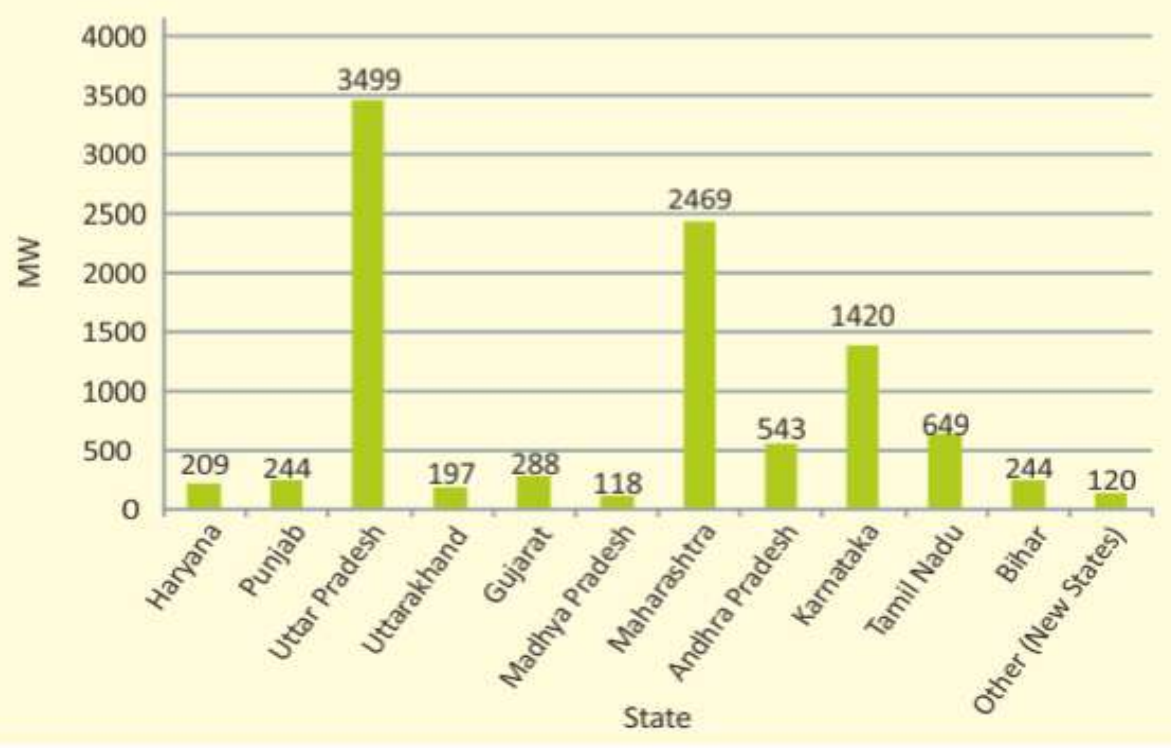

Figure 2:- Renewable power targets by 2022 state wise [5]

\section{Sources For Bio Gas Production:-}

\section{A. Animal wastages:}

Farming waste is a natural material and can be utilized to deliver biogas through anaerobic assimilation, hence giving another option to Agriculture squander utilizes and moderating the contamination. Agribusiness squander is fundamentally made out of three gatherings of polymers, to be specific cellulose, hemicelluloses, and lignin. Cellulose and hemicelluloses are sugar rich divisions of enthusiasm for use in maturation forms [7].

In TN, and MP more number of cow cattle are maintained by farmers and some co operative unions, Self help groups. The cows are used for Milk production .Here the disposal of the wastages like cow dung are the major problems. Namakkal, in Tamilnadu which is famous for chicken \& Egg export. The poultries are also facing the same problems. They are used to dumb those wastages in open air environment, due to the chemical digestion process the methane gas produces and mixed with atmospheric air causes odour, health issues to human beings, and causes the global warming effects [1].

\section{B. Industrial waste:}

Anaerobic methodologies are by and large used for the treatment of current misuses and waste water for extra than a century and $\mathrm{AD}$ is today a standard development for the treatment of different modern. Waste waters from sustenance taking care of, agro-endeavors, and pharmaceutical organizations. Ad is moreover associated with pretreat normal stacked current waste waters, previously positive exchange. In view generally upgrades of treatment advancements, debilitated mechanical waste waters can in like manner be handled [8].

\section{Household waste:}

Biogas innovation programs keep running more than 60 years of age in India by the orderly improvement and advancement of family (Hh). To start with instatement of family unit biogas plants in India by the KVIC, under the showing and usage by utilizing the gliding steel holder demonstrate in 1960. Be that as it may, usage of Hh in India by the by the administration under the DNES now it change into MNRE. Administration of India eats these plans know as National Project on Biogas Development (NPBD), in 1981-82 [5].

\section{Hazardous waste:}

Waste and waste lessening are progressively turning into the concentration of various national organizations and ecological offices around the globe. Nation must bend over backward to stem the rising tide of trash and modern waste through a more forceful utilization of waste minimization and reusing hones. 
Worldwide shipments of risky squanders are the essential concentration of this record, the introduction expresses that the signatory gatherings to this tradition were roused by the possibility that, "the best method for shielding human wellbeing and the earth from the perils postured by [hazardous] squanders is the decrease of their era to a base as far as amount as well as danger potential [10].

Modern and healing center waste is viewed as risky as they may contain poisonous substances. Certain sorts of family unit squander are likewise perilous. Unsafe squanders could be exceedingly harmful to people, creatures, and plants; are destructive, exceptionally inflammable, or hazardous; and respond when presented to specific things e.g. gasses. India creates around 7 million tons of dangerous squanders each year, a large portion of which is gathered in four states: Andhra Pradesh, Bihar, Uttar Pradesh, and Tamil Nadu.

\section{E. Agriculture waste:}

Horticulture squander is a natural material and can be utilized to create biogas through anaerobic processing, along these lines giving a contrasting option to Agriculture squander utilizes and moderating the contamination. Agribusiness squander is for the most part made out of three gatherings of polymers, to be specific cellulose, hemicelluloses, and lignin. Cellulose and hemi cellulose are sugar rich divisions of enthusiasm for use in maturation forms [7].

\section{Rice Straw}

-1 ton of Rice paddy produces $290 \mathrm{~kg}$ Rice Straw

- $290 \mathrm{~kg}$ Rice Straw can create $100 \mathrm{kWh}$ of energy

-Calorific esteem $=2400 \mathrm{kcal} / \mathrm{kg}$

\section{Rice Husk}

- 1 ton of Rice paddy produces $220 \mathrm{~kg}$ Rice Husk

- 1 ton Rice Husk is proportionate to 410-570 $\mathrm{kWh}$ power

- Calorific esteem $=3000 \mathrm{kcal} / \mathrm{kg}$

-Moisture content $=5-12 \%[11]$

\section{F. Kitchen waste:}

This incorporates sustenance waste, wash and waste water. Kitchen squanders concede vegetables squander, waste, softened material which are found up homes and these are arranged into open zones. "Sustenance squander" alludes to nourishment that is of good quality and fit for human utilization however that does not get devoured since it is arranged. Natural products, drain, paper, Fish, Food cooked however not eaten, eggs, Chicken, bosoms, Mushrooms, Lemons, Fruit pies, Onions, Mixed vegetables.

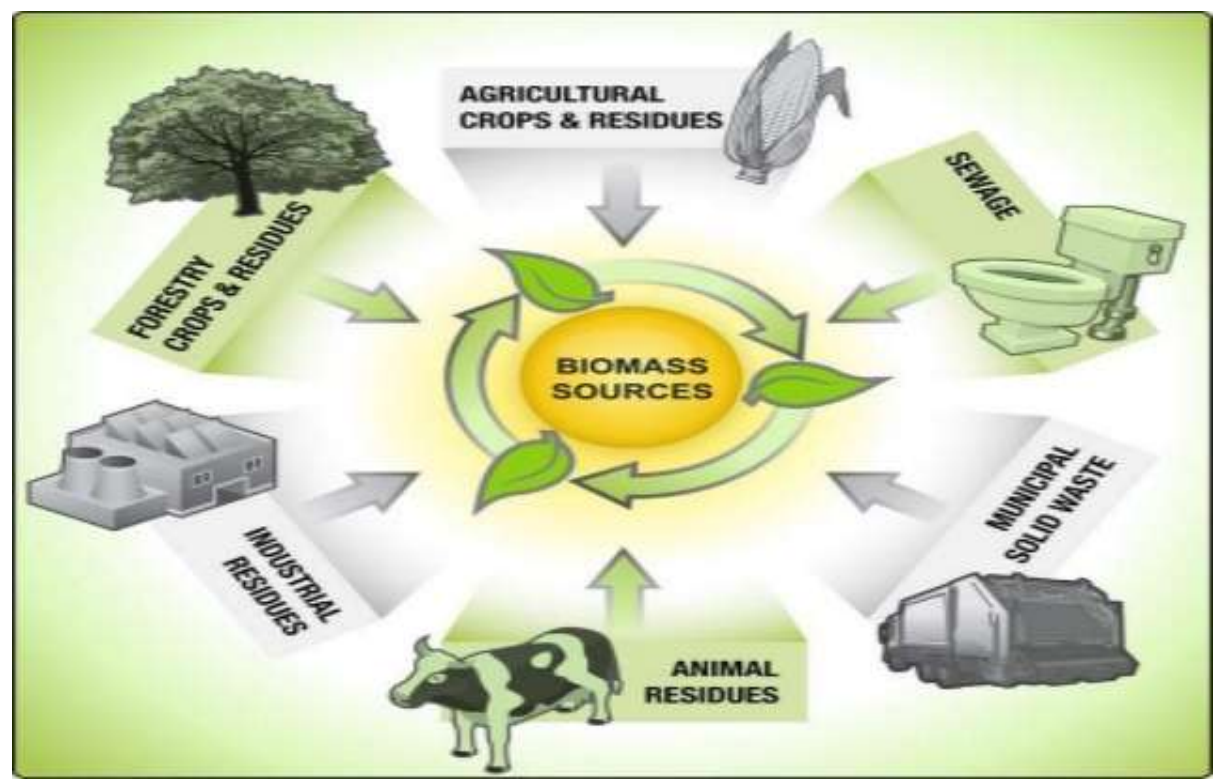

Figure 3:- Resources of production of biomass [7] 


\begin{abstract}
Benefits Of Biogas:-
Energy Benefit: Biogas contains basically CH4 (60\%-70\%), which is an indistinguishable vitality transporter from in petroleum gas. Along these lines, biogas and gaseous petrol can be utilized for same application. Methane can be scorched for cooking or lighting the house. It can likewise be utilized to control burning motors to drive a mechanical engine or create power [12].
\end{abstract}

Economic Benefit: Biogas has two sorts of financial advantages one is it spares the vitality cost to be obtained and then again additional cash can be earned by offering bio gas to the neighbors [12].

Carbon credit: The IPCC is as of now done Sixth evaluation cycles. In this cycle, the give the three exceptional reports, a philosophy give an account of green house gas inventories and the 6th evaluation report (AR6).

The 43rd session of the IPCC held in April 2016 concurred that the AR6 union report would be settled in 2022 in the ideal opportunity for the principal UNFCCC worldwide stock take when nations will survey advance towards their point of keeping a dangerous atmospheric deviation to beneath $2{ }^{\circ} \mathrm{C}$ while seeking after push to limits it to $1.5{ }^{\circ} \mathrm{C}$ [13].

Agriculture Benefit: Cow dung and the organic waste are converted into slurry in the biogas power plant. After the use of slurry it can be used as organic fertilizers. The waste slurry is very used in grove the plants. Nitrogen is providing most important role to grove the plant. Before going used this organic compound we have to mineralize with the nitrogen compound. Because in the cow dung most of the nitrogen is not immediately available to crops grow. In the conversion process, that takes place in a biogas plant, the organic nitrogen in the cow dung are mineralized to ammonium (NH+) and nitrate (NO3-) [14].

Health Benefit: During the conversion a lots of micro-organism are present in there that represent the health risk or killed. With hygienic standard risk is improved in the household. Some of the germ killed in biogas digester. The following are:

- Typhoid

- Paratyphoid

- Cholera and loose bowels microbes (in maybe a couple weeks)

- Hookworm and bilharzias (in three weeks)

- Tapeworm and roundworm bite the dust totally when the matured slurry is dried in the sun [15]

Environmental Benefit: Delivering biogas from domesticated animal compost can lessen scent in light of the fact that the slurry does not create extreme smell and does not draw in flies. Moreover, it helps lessening water tainting hazard when it comes in contact with dairy animal excrement, Pathogen decrease, Methane pulverization/catch through digester [12].

\title{
Biogas Energy Production Process:-
}

There are varies type of the process for the production of Biogas. According to the resource available, selection of site, environment, and climate condition for the transportation and other purpose throughout the whole years. There are maximum four processes for the production of the methane gas. 


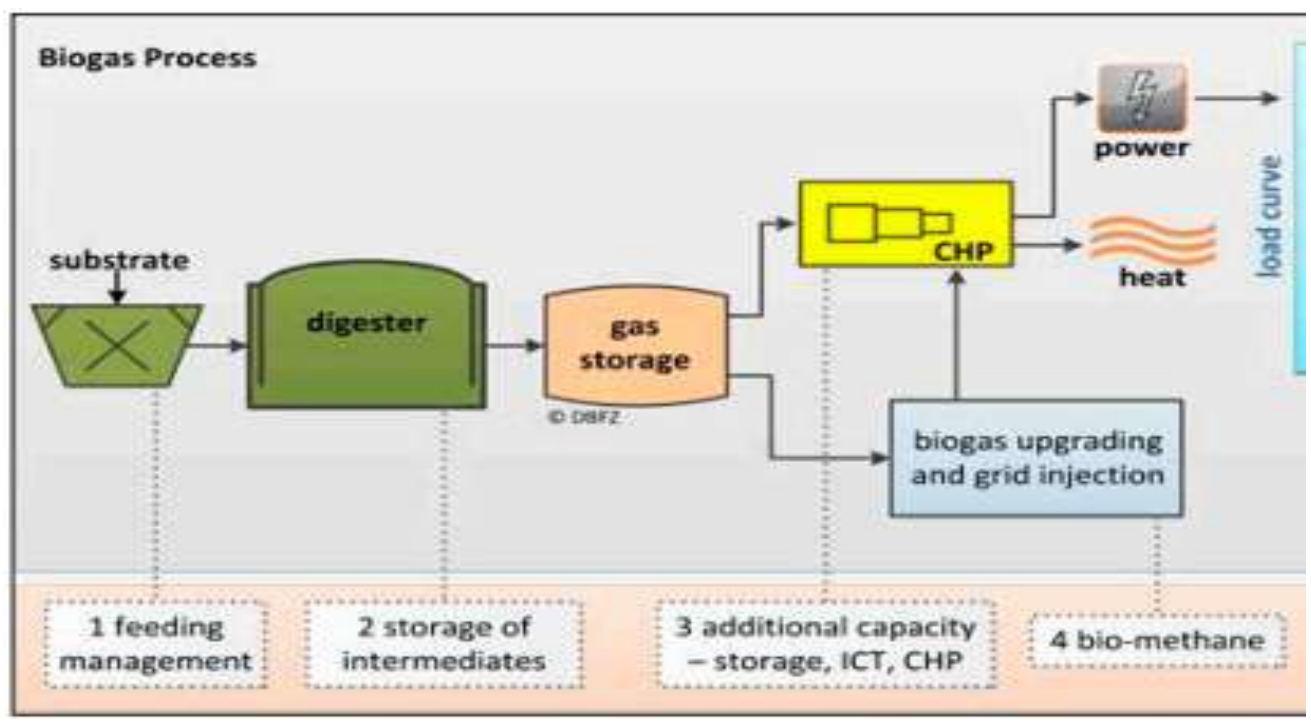

Figure 4:- Biogas power plant process [17]

In the figure (4) show that the process of electricity generations by the biogas. Biogas is produced by microorganism in the absent of the air this process is called Anaerobic Metabolisms. Industrial biogas is produced at sewage treatment plants (sludge fermentation stage), landfills, and sites with industrial processing industry and at digestion plants for agricultural organic waste by using mesophilic and thermophilic. Biogas process anaerobic metabolisms and landfills consisting of $\mathrm{CH} 4$ and $\mathrm{CO} 2$ [9].There is following process of anaerobic metabolisms as show in figure (5)

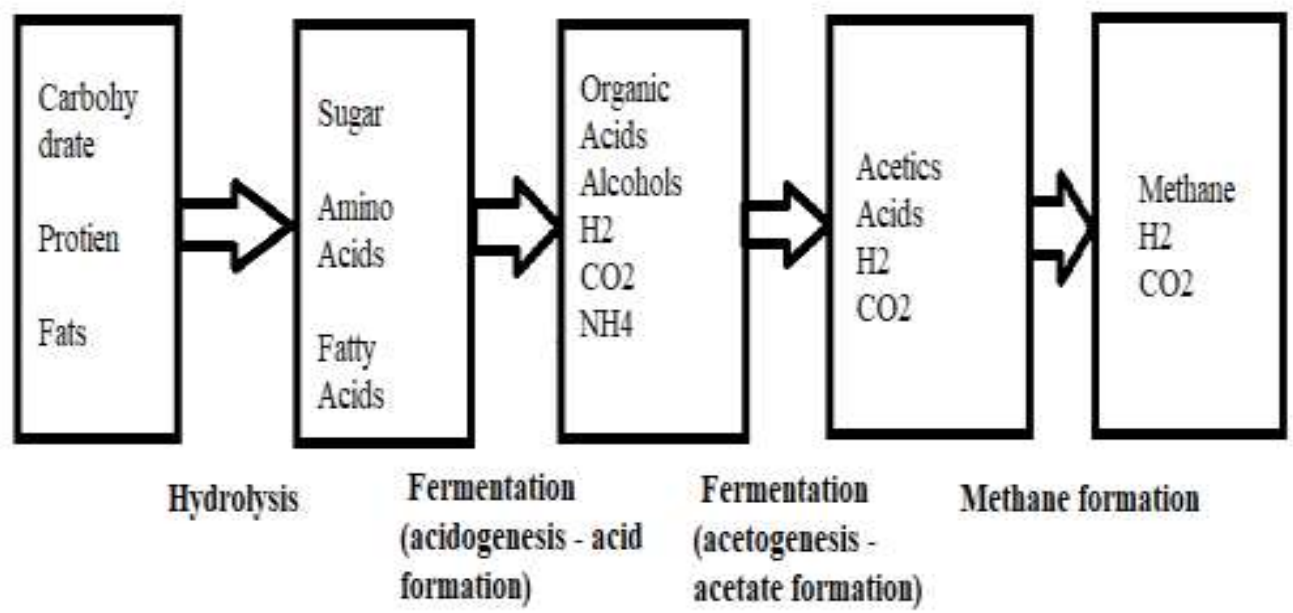

Figure 5:- Process of Anaerobic Metabolism

For the production of biogas three fundamentals biochemical processing hydrolysis, acidogenesis/acetogenesis and methane-genesis.

$(\mathrm{C} 6 \mathrm{H} 10 \mathrm{O} 5(\mathrm{C} 6 \mathrm{H} 10 \mathrm{O}) \mathrm{n}+\mathrm{nH} 2 \mathrm{O} \rightarrow \mathrm{n}(\mathrm{C} 6 \mathrm{H} 12 \mathrm{O} 6)-$ Hydrolysis

$\mathrm{n}(\mathrm{C} 6 \mathrm{H} 12 \mathrm{O} 6) \rightarrow \mathrm{nCH} 3 \mathrm{COOH}$-Acetogenesis/Acidogenesis

$3 \mathrm{nCH} 3 \mathrm{COOH} \rightarrow \mathrm{nCH} 4+\mathrm{CO} 2-$ Methanogenesis

The last reaction step is the production of methane from products of the previous steps. The first three steps can be taken together as the acid forming step with methane formation as the final step.

The digester will produce biogas and digestate. The biogas consists of the main components methane (CH4) 60\% and Carbon dioxide (CO2) $40 \%$. It will also contain small amounts of nitrogen $(\mathrm{N})$ and is saturated with water (H2O). The biggest polluting element is hydrogen sulfide (H2S). 


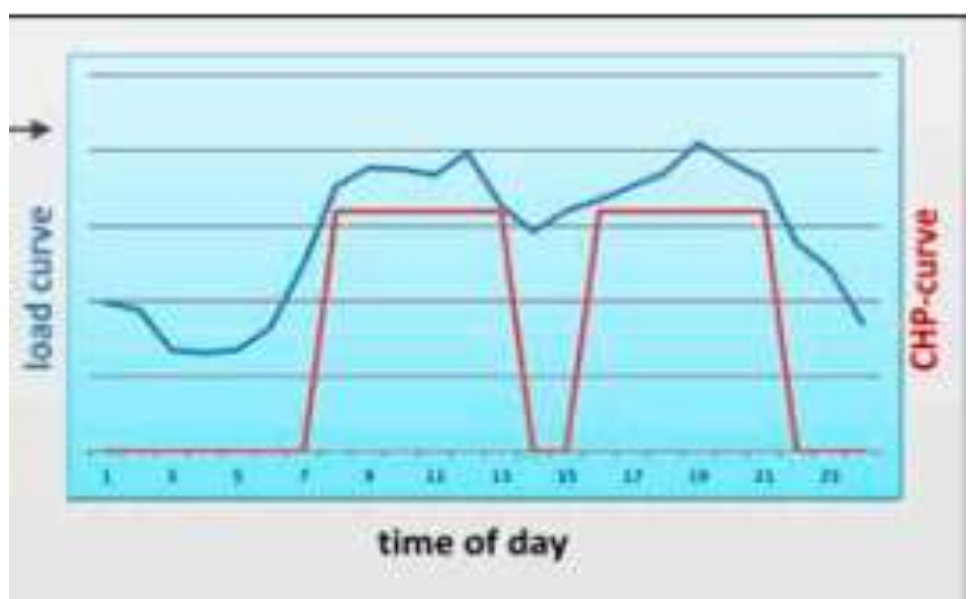

Figure 6:- Load flow curve per day for the biogas power plant [17]

The following table contains the design parameters for the digestion system [16]

\begin{tabular}{|l|l|l|}
\hline Parameters & $\begin{array}{l}\text { Desired } \\
\text { value }\end{array}$ & Unit \\
\hline Digestion volume & 600 & $\mathrm{~m} 3$ \\
\hline Residence time & $>25$ & Days \\
\hline Daily digester input & $<25$ & $\mathrm{~m} 3 /$ day \\
\hline Temperature inside the balloon & $35 \pm 3$ & ${ }^{\circ} \mathrm{C}$ \\
\hline Maximum allowable temperature change & 1 & ${ }^{\circ} \mathrm{C} /$ day \\
\hline
\end{tabular}

$\mathrm{HHV}, \mathrm{C}$ conversion and energy conversion can be calculated by Equations 1 to 2

C conversion $(\%)=\frac{\sum C(\text { biogas })}{C(\text { waste })}$

Energyconversion $(\%)=\frac{\sum H H V(\text { biogas })}{H H V(\text { waste })}$

\section{Smart Grid:-}

As per the "International Electrotechnical Commission" (IEC), "Savvy Grid is the idea of modernizing the electric lattice. The Smart Grid is coordinating the electrical and data advances in the middle of any purpose of Generation and any purpose of Consumption".

As per "NIST" has additionally built up the Smart Grid Conceptual Model which gives an abnormal state system to the keen lattice that characterizes seven vital areas: Bulk Generation, Transmission, Distribution, Customers, Operations, Markets and Service Providers where control quality has been accepted as a vital part in the Smart Grid Network. The quantity of network frameworks like Wind Energy Systems and Photovoltaic are presently sharp more into the lattice and also the quantities of non-direct loads is likewise expanding. Smart energy grids potential play a special role for the biogas. Biogas system may be help to increase the proportions of variable on renewable electricity on the electricity grid by using of two different technologies [17].

- Biogas frameworks which increment the generation of power at the season of popularity for the power, or store the biogas incidentally at the season of low power request.

- This resolve to biogas plant if the less interest for power low than supply of power to framework, accommodating surplus power to gas.

In created nation to such an extent that preferences Germany, Brazil and Ireland with wide biogas framework. They are run their plant in such path that to expand the creation of power from biogas if the request is increments. Biogas control plant is putting away the power request is high as well as by nourishing when the request is high as show in figure (7A) . The other one framework is named Power to gas is appeared in figure (7B). This requires changing over sustainable power to hydrogen $(\mathrm{H} 2)$ utilizing electrolysis when the power generation is high yet request is low. And furthermore the ventures and foundation are connected with the hydrogen as a vehicles fuel, or as a vitality, it 
has exceedingly used to created vitality. Dissemination frameworks or end clients are not set up. However methane request is builds step by step as a petroleum gas dissemination frameworks and methane is broadly coursed toward the end client, across the board range of methane from home warming to flammable gas vehicles (NGS) to consolidated cycles gas turbine control (CCGT) plants. Through the procedure of methanation hydrogen can be utilized to deliver methane by two strategies: synergist transformation or organic change. Methane created from surplus power by means of hydrogen might be infused to a current gas matrix; this takes into account stockpiling of the vitality and furthermore changes the vitality vector from power to gas. The capacity limit and span of capacity of methane is in well in abundance of generally other vitality stockpiling frameworks figure (5). The green gas or biogas can be utilized for the inexhaustible warmth and transportation fuel or as sustainable power if the request increments over and over. So this connection innovation is conceivably is called segment of future savvy matrix There is little distinction between methane from energy to methane and flammable gas in the framework; both are overwhelmed by methane despite the fact that gaseous petrol may have little amounts of higher hydrocarbons, for example, ethane $(\mathrm{C} 2 \mathrm{H} 6)$, propane $(\mathrm{C} 3 \mathrm{H} 8)$, butane $(\mathrm{C} 4 \mathrm{H} 10)$ or pentane $(\mathrm{C} 5 \mathrm{H} 12)$. These higher hydrocarbons increment the vitality estimation of flammable gas [17].

This paper has the target of giving a point of view on the part biogas can play in adjusting the power lattice. At the point when power request is high, request driven biogas ideas can be utilized to build power yield figure 7 (A). At the point when irregular sustainable power creation surpasses request, energy to gas frameworks might be utilized to change over power to methane figure $7(\mathrm{~B})$.

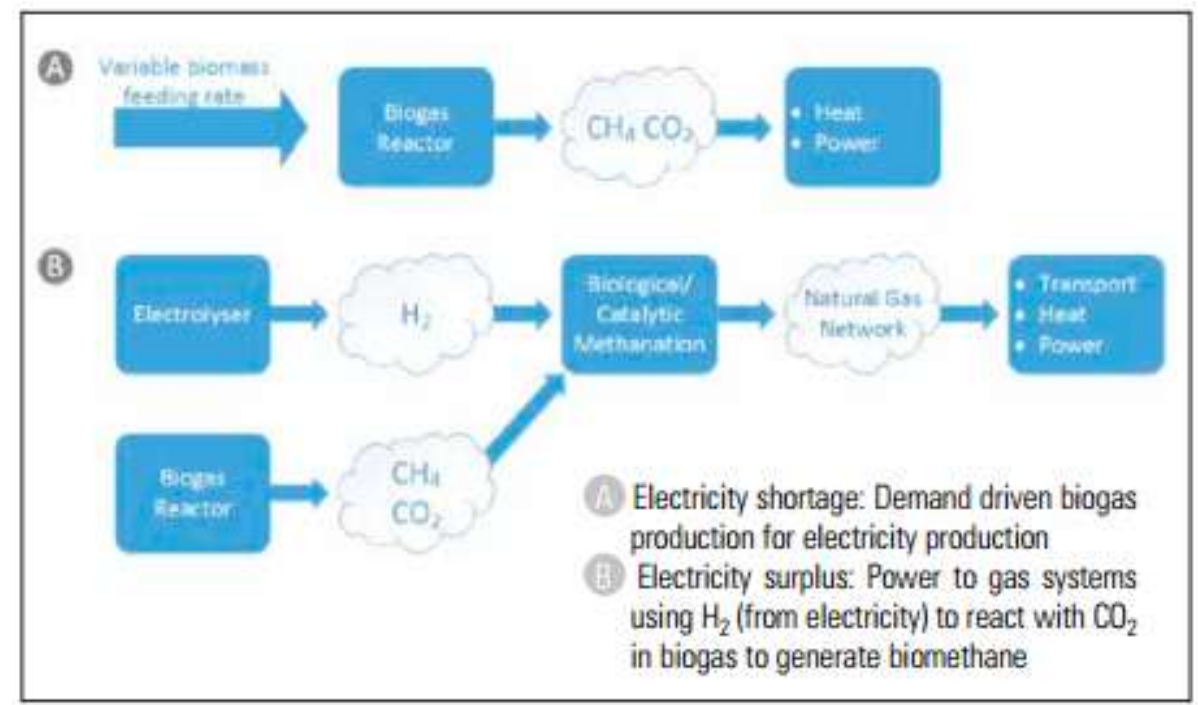

Figure 7:- Demand driven biogas production for electricity production and electricity surplus [17]

\section{Electrolysis:-}

The first step in a Power to Gas system is electrolysis and production of hydrogen. Electrolysis is an electrochemical reaction, where direct electrical current (DC) is used to split water into its constituent elements, oxygen and hydrogen, according to Equations. There are some of the Electrolysis technologies shown following table (1).

$2 \mathrm{H}_{2} \mathrm{O}(\mathrm{l}) \rightarrow 2 \mathrm{H}_{2}(\mathrm{~g})+\mathrm{O}_{2}$

$\Delta \mathrm{Hr}=286 \mathrm{~kJ} / \mathrm{mole}\left(\right.$ at $\left.25^{\circ} \mathrm{C}, 1 \mathrm{bar}\right)$ 


\begin{tabular}{|c|c|c|c|}
\hline & AEC & PEM & SOEC \\
\hline Type of electrolyte & $20-30 \% \mathrm{KOH}$ in $\mathrm{H}_{2} \mathrm{O}(\mathrm{l})$ & Polymer, e.g. NAFION@ & $\begin{array}{l}\text { Ceramic of yttria-stabilized } \\
\text { zirconia (YSZ) }\end{array}$ \\
\hline Type of electrodes & Ni-based & $\mathrm{Pt} / \mathrm{C}$-based & $\begin{array}{l}\text { Ni-based }\left(\mathrm{H}_{2}\right) \\
\text { Perovskite }\left(\mathrm{O}_{2}\right)\end{array}$ \\
\hline Type of membrane & $\begin{array}{l}\text { Asbestos or asbestos-free } \\
\text { polymer }\end{array}$ & Same as the electrolyte & Same as the electrolyte \\
\hline Temperature & $60-80^{\circ} \mathrm{C}$ & $50-80^{\circ} \mathrm{C}$ & $700-1000^{\circ} \mathrm{C}$ \\
\hline Pressure & $<30$ bars & $<30$ bars & under evaluation \\
\hline Power density & $\leq 1 \mathrm{~W} / \mathrm{cm}^{2}$ & $\leq 4 \mathrm{~W} / \mathrm{cm}^{2}$ & under evaluation \\
\hline Part load range & $20-40 \%$ & $0-10 \%$ & $0-10 \%$ \\
\hline Efficiency ${ }^{\top}$ & $\begin{array}{l}60-70 \% \text {, corresponding to } \\
\text { the power consumption } \\
4-5 \mathrm{kWh} / \mathrm{Nm}^{3} \mathrm{H}_{2}\end{array}$ & $\begin{array}{l}60-70 \% \text { corresponding to } \\
\text { the power consumption } \\
4-5 \mathrm{kWh} / \mathrm{Nm}^{3} \mathrm{H}_{2}\end{array}$ & $\begin{array}{l}90-95 \% \text {, corresponding to } \\
\text { the power consumption } \\
3-3.3 \mathrm{kWh} / \mathrm{Nm}^{3} \mathrm{H}_{2}\end{array}$ \\
\hline
\end{tabular}

\section{Conclusions:-}

This paper will give the idea about installation of biogas power plant in India. This is not more popular power plant due to the awareness and proper motivation in the people. So it is necessary awareness to ruler population to benefit of biogas power plants. The main factor of this is to choose location based on the cow firm, poultry firm easily available to various states.

The Operation principles and biogas generation procedures, Effective utilization of wastes to produce electricity were discussed. Similarly biogas can be generated from the sewage waters processing also. In this most important is discuss about the health benefit. Discuss about the process of the production of methane and hydrogen gas for the renewable. The green gas or biogas can be used for the renewable heat and transportation fuel or as renewable electricity. Also discuss about the connection with smart grid or micro-grid or the grid system.

The biogas production plants were installed in some locations as pilot basis by Government of India and private Institutions collaboration mode. More initiatives and awareness among the investors are to be created as part of the Green Energy Program.

\section{References:-}

1. G.D.ROY, "The Non-conventionl energy resources, Kanna publishers, 1993".

2. 3-year road map for power sector reform (2008 - 2010). "Power Division Ministry of Power, Energy and Mineral Resources Govt. of the People's Republic of Bangladesh"

3. https://www.iatp.org/news/agricultural-waste-creates-fields-of-gold-in-rural-india

4. Annual report government of India 2014- 2015

5. Annual report government of India 2016-2017

6. Asokan Pappua,, Mohini Saxenaa, Shyam R. Asolekarb "Solid wastes generation in India and their recycling potential in building materials".

7. TR Sneha R. Vattamparambil, "Anaerobic Microbial Hydrolysis of Agriculture Waste for Biogas Production, International Conference on Emerging Frontiers in Technology for Rural Area (EFITRA-2012)".

8. University of Southern Denmark Esbjerg, NielsBohrsVej 9-10, DK-6700 Esbjerg, Denmark, Teodorita Al Seadi, DominikRutz, Heinz Prassl, Michael Köttner, Tobias Finsterwalder, Silke Volk, Rainer Janssen, ISBN 978-87- 992962-0-: Copyright (C) 2008" 
9. Patricia cekanova,natalia jasminska, Tomas brestovic,Eva schvarzba cherova, "Biogas upgrading process for the production of natural gas substitute", ISSN 1848-0071 ,(24 may 2011)".

10. Christa D. Jensen, "Who Generates Hazardous Wastes? Attribution of Producer and Consumer Responsibility within the US", Regional Research Institute, Department of Economics, West Virginia University, PO Box 6825, Morgantown, RESEARCH PAPER 2010-16

11. Biomass Resources from Rice Industry by salman Zafar November 2015"

12. ASM. Mominul Hasan1, M. Fayyaz Khan1 "Community Based Bio Gas plants for SocioEconomic Development of Rural Bangladesh"Department of EEE, United International University (UIU), Dhaka, Bangladesh"

13. "IPCC inter governmental panel on climate Change AR6 scoping meeting Addis Ababa, Ethiopia, 1 - 5 May 2017" AR6-SCOP/Doc. 2

14. Tami, Noelle, Dani, and Mike, Organic vs. Chemical Fertilizers, January 31, 200, "http://jrscience.wcp.muohio.edu/nsfall01/FinalArticles/Final3Organicvs.ChemicalF.htm"

15. Biogas Users' Survey 2000, The Biogas Sector Partnership+Nepal (BSP+Nepal)

16. "Bio-Gas Power Plants -Green Energy options for Indian villages" Anbu Elango R, Mohan P, IEEE

17. Tobias Persson, Jerry MurPhy, Anna-Karin JAnnAsch, eoin Ahern, Jan LiebeTrAu, Marcus TroMMLer, Jeferson ToyAMA "A perspective on the potential role of biogas in smart energy grids. 